\title{
SEGMENTATION OF LIFESTYLE OF S1 STUDENTS FACULTY OF ISLAMIC ECONOMICS AND BUSINESS UNIVERSITY OF ISLAM KIAI HAJI ACHMAD SIDDIQ JEMBER
}

\author{
Mohammad Mirza Pratama \\ University of Islam Kiai Haji Achmad Siddiq \\ mirzha.jo@gmail.com
}

\begin{abstract}
Segmentation is not only used by companies in determining policies to dominate the market, but segmentation is able to provide an overview or information on human lifestyles, especially students of the Faculty of Economics and Islamic Business at Kiai Haji Achmad Siddiq State Islamic University Jember. In the world of education, segmentation is able to provide information about students, then the information will be used to compile academic programs that have the essence of the character of students.

This research uses action research methods or action testing without research, that is, researchers do not carry out systematic research according to the rules of research methodology. This is because the researcher is a lecturer at the Faculty of Economics and Islamic Business at the State Islamic University of Kiai Haji Achmad Siddiq Jember. In this study, students of the Faculty of Economics and Islamic Business have three criteria or segments, namely dynamic students, identity seeking students and conservative students.

Keywords : Segmentation, dynamic student and lifestyle, conservative identity
\end{abstract}

\section{INTRODUCTION}

Segmentation is an attempt to divide the population into groups that can be distinguished from one another. One branch of science that benefits a lot from segmentation is marketing. In marketing, the term market segmentation is known, which means trying to divide the market into groups that can be distinguished from each other in terms of needs, characteristics, or behavior. These groups may need specific products and marketing strategies to reach these groups. (Kotler and Armstrong, 2004:284).

Market segmentation is dividing the market into distinct groups of buyers, which may require separate marketing or products (Armstrong, 1997: 227). So market segmentation is an attempt to group the heterogeneous market into groups of potential buyers who may be able to differentiate from the desired potential buyers.

You can tap into market segments and serve them more effectively. In addition, a wellsegmented market is easier to manage because a segment tends to give a homogeneous response to a stimulus. Understanding the needs, characteristics, or behavior of market segments will make it easier for marketers to target market segments effectively (Kotler and Armstrong, 2004).

Apart from commercial activities, market segmentation can also be used to promote new laws, launch social campaigns, send political messages, stimulate religious life, and educate students (Kasali, 1998).

From the information above, the researcher is interested in implementing segmentation in the world of education, especially in the academic world, through basic descriptive research, it can be seen that the segmentation of students from the Faculty of Economics and Islamic Business, Kiai Haji Achmad Siddiq State Islamic University Jember.

Kotler and Armstrong (2004) show that there is no single method for good market segmentation. However, there are several main variables that are often used as differentiating factors to divide the population into groups or market segments. 
People with the same demographics can have psychological characteristics very different. One of the most common psychological factors used by marketers is the lifestyle of the customer (Kotler and Armstrong, 2004).

Kiai Haji Achmad Siddiq State Islamic University Jember is a campus in Jember Regency whose existence has been able to bring a big name because it has produced potential graduates in their respective scientific fields. However, the more competition in the world of education as it is today, the State Islamic University of Kiai Haji Achmad Siddiq Jember has to improve in order to be able to dominate the market, especially in the Jember region and its surroundings. The more developed a university is, the more complex the problems faced, then the more the characteristics of the identity of each student in each study program will increase.

Based on the information above, the researcher will segment based on lifestyle as a differentiating variable or a variable that becomes the size of students of the Faculty of Economics and Islamic Business at Kiai Haji Achmad Siddiq State Islamic University Jember.

\section{Problem Formulation and Research Objectives}

In accordance with the information and background above, the researcher will formulate the following problem, how is the lifestyle segmentation of the students of the Faculty of Economics and Islamic Business at the Kiai Haji Achmad Siddiq State Islamic University Jember? While the purpose of this study was to determine the lifestyle segmentation of the students of the Faculty of Economics and Islamic Business at the State Islamic University of Kiai Haji Achmad Siddiq Jember.

\section{Literature Review Market Segmentation}

Kotler and Armstrong (2004), marketing segmentation is an attempt to divide the market into groups that can be distinguished from each other in terms of the possible needs, characteristics, or behavior of certain products and marketing strategies to reach them.

Kasali (1998), market segmentation has been developed extensively. Market segmentation is not only used for the purpose commercial, but also for community activities or other nonprofit activities.

Pride \& Farrel (1995) say that market segmentation is the process of dividing the market into segments of potential customers with similar characteristics. These potential customers exhibit similarities in buyer behavior and divide the entire market into relatively equal segments. The process of forming a market group of people. product demand.

By because that, from multiple perspectives the above segmentation, segmentation is an effort to group the population used for activities within a company, which aims to match the characteristics and showbehavior buyer, and divide all markets into groups with the following characteristics: following. market groups formed by society must be the same.

Kotler and Armstrong (2004) wrote four main variables commonly used in market segmentation. These variables are geography, demography, psychology, and behavior.

A broad market has people or organizations with very diverse or heterogeneous conditions. Therefore, they need to be divided into groups with the same or similar (homogeneous) characteristics or conditions to form market segments. Therefore, market segmentation is an attempt to group heterogeneous markets into several parts.

\section{Lifestyle}

Assael (1984), lifestyle is "A mode of living that is identified by how people spend their time (activities), what they consider important in their environment (interest), and what they think of themselves and the world around them (opinion )" 
Minor and Moven (2002), lifestyle shows how people live, spend money and allocate time. Suratno and Rismiati (2001) Lifestyle is a person's lifestyle in the world oflife everyday, which is manifested in activities, related interests and opinions . Suratno and Rismiati (2001) Lifestyle is a person's lifestyle in the world oflife everyday, which is manifested in activities, related interests and opinions .

Referring to the above theory, lifestyle is showing how people live to spend their money, allocate it in daily life which is expressed in the activities, interests and opinions concerned. Lifestyle is a picture for everyone who uses it, describing the person's moral values in the surrounding community. Or lifestyle is an art that everyone can develop. There is tendencies specialinthe way of life, man wants to show his abilities. In fact, lifestyle is a social trend that often becomes an official or unofficial debate, but the conclusions obtained about lifestyle are still struggling with themodel style carried out by mankind. In another sense, lifestyle can have aimpact positive or negativeon people who live in it, depending on the style the person's life .

Contrary to Kasali (1998), market researchers who insist onmethods lifestyletend to classify consumers based on AIO variables, namely activities, interests, and opinions.

Joseph Plumer (1974) said that the division of lifestyle measures activity humaninthe following aspects:

1. person's pattern of spending his time

2. Someone's interest

3. One's view of oneself and others

4. Basic characters such as the stages a person goes through in life (life cycle), income, education, and where they live.

This approach uses a combination of several theories, namely:

1. The Hierarchy of Needs Theory was developed by Abraham H. Maslow. In other words, humans transmit five levels of needs in stages: basic physiological needs, security, belonging, respect, and self-realization.

2. The theory ofthe inner and outer directed personality theory introduced by Riesman, Glazer and Denney (1950).

\section{Previous research \\ Framew ork for thinking}

From the information above, the thinking framework of this research is that if students of the Faculty of Economics and Islamic Business at the State Islamic University of Kiai Haji Achmad Siddiq Jember are considered, then they will have three lifestyle modes, enthusiastic students, students who are looking for identity, and trend makers.

\section{Research Methodology}

1. Writing approach

The writing approach uses a qualitative descriptive method based on literature review and direct observation in the field, especially for students of the Islamic Economics and Business Faculty at Kiai Haji Achmad Siddiq State Islamic University Jember. By choosing this method, it is hoped that it can provide a detailed description of certain conditions or symptoms in the object of research. This paper describes the lifestyle of the students of the Faculty of Economics and Islamic Business at the State Islamic University of Kiai Haji Achmad Siddiq Jember.

This research is a research evidence of action without research According to Sugiyono, (2014:700) This type of research is that researchers have not conducted research systematically according to the rules of research methodology to find problems, diseases, potentials, strengths, and weaknesses. 
The action to be tested is based on on analysis problem, which is not based on research, but on assumptions and perceptions that are consideredsymptoms negative (Sugiyono, 2014: 700).

Basically, this action research without research will be used to identify student segments, especially the Faculty of Economics and Islamic Business at the State Islamic University of Kiai Haji Achmad Siddiq Jember, and is based on the suggestions of previous researchers or suggestions from participants and observers.

The method used in this action research is learning history, (Sugiyono, 2014: 704) this research is used as learning material in action research. Researchers collaborate with active people or students who are involved in organizational or academic activities to tell the history of the development of the lifestyle of students of the Faculty of Economics and Islamic Business at Kiai Haji Achmad Siddiq State Islamic University Jember with this action research.

2. Method of collecting data

There are two data collection methods used, namely primary data and secondary data. Secondary data includes books that are relevant to the topic of writing, scientific papers, journals and articles from the internet. Primary data comes from the object of research, especially the number of students of the Faculty of Economics and Islamic Business at the State Islamic University of Kiai Haji Achmad Siddiq Jember. From some of these sources, it is hoped that it will strengthen the discussion so that it will become a scientific work.

\section{Hypothesis}

Based on the description framework Previously, according to (Sugiyono, 2014:722), the action research is not hypothesisa statistical hypothesis but a theoretical hypothesis.hypothesis The theoretical is a hypothesis that can describe the response survey time and not accompanied by numbers. So the hypothesis of this research is:

H1 : The lifestyle of students of the Faculty of Economics and Islamic Business at the State Islamic University of Kiai Haji Achmad Siddiq Jember is very dynamic, seeking identity and being conservative.

\section{Action research process}

Sugiyono, (2014:707) suggests that the action research process uses action tests without research, so to find problems, this type of research only reflects the work situation or situation of the object of investigation, opinion and empirical research. to formulate a formula. Research the question and its title.

Action research in this case is the researcher making observations to the location or field, because the existing problems are clear and appropriate for action, the researchers describe the lifestyle of the students of the Faculty of Economics and Islamic Business at the Kiai Haji Achmad Siddiq State Islamic University Jember, so that empirically action research will be able to answer it.

Planning, implementing actions (Act), evaluation (Observe), reflection (Reflect) and conclusions. The data collection technique uses secondary data, which contains about the problems that occur, then from the results of the interviews, the research conducts data assessments and tests action hypotheses.

Observations were made by visiting the students who were directly involved and by noting their lifestyle. When the students make comments about their lifestyle, the researcher takes notes on how the students behave, do activities, etc.

\section{Research Instruments}

The instrument of this research is to use and observe interviews and then record the results of these interviews to a number of students, namely 30 , because the interview process uses 35 respondents, the researchers use numbers $4=$ very high, $3=$ high, $2=$ low and $1=$ very low, (Sugiyn, 2014:724). Because the number of students of the Faculty of Islamic Economics and 
Business at the State Islamic University of Kiai Haji Achmad Siddiq Jember has a very large number, the researchers took a sample of 35 students, this is in accordance with Sugiyono's theory, 2014:725.

Table 1

Differentiating Instruments

\begin{tabular}{|l|l|l|l|l|l|l|l|l|l|}
\hline \multicolumn{3}{|c|}{$\begin{array}{c}\text { Before becoming a } \\
\text { student }\end{array}$} & $\begin{array}{l}\text { After becoming a } \\
\text { Aspects } \\
\text { assessed }\end{array}$ & \multicolumn{3}{c|}{ Difference } \\
\hline 1 & 2 & 3 & 4 & Lifestyle & 1 & 2 & 3 & 4 & \\
\hline 1 & 2 & 3 & 4 & Student & 1 & 2 & 3 & 4 & \\
\hline 1 & 2 & 3 & 4 & $\begin{array}{l}\text { Hangout } \\
\text { locations }\end{array}$ & 1 & 2 & 3 & 4 & \\
\hline
\end{tabular}

Source: Sugiyono, 2014:724 in IMARC, 2014 which was developed by researchers

\section{Data Analysis Techniques}

In this study the data analysis technique is to test the hypothesis, then the cycle is:

The lifestyle of students of the Faculty of Islamic Economics and Business at the State Islamic University of Kiai Haji Achmad Siddiq Jember is very dynamic, seeking identity and being conservative.

\section{Results and Discussion}

Student Lifestyle, Joseph Plumer (1974) for example said that lifestyle segmentation measures human activities in terms of the following:

1. How students spend their time

2. Students' interests, especially those that are considered important

3. Students' views of others and themselves

4. Basic characteristics such as the stage they have gone through in life (life cycle), education income, and where they live.

From the opinion of Joseph Plumer and the self-administrated quastionaire design and the author discusses the things found in the field observations, namely:

1. The way students spend their time is seen from the time allocated for studying and doing assignments

2. Students' interest can be seen from their favorite activities

3. The views of students consist of several initiatives related to the views of students about the existence of the surrounding environment

Basically, students with economics faculties such as HR and finance, have a tendency to determine opportunities, which have a vision of working in the room or become administrative staff by dwelling on numbers and the workload.

On that basis, students of the Islamic economics and business faculty have activities in certain fields related to the potential for self-development including gathering to do fieldwork assignments.

For students in other faculties, then it is possible they will also do the same thing, but there kecnderungan system it uses has a system of order, sequence and tersistematis, as students from the Faculty others see the numbers as something tersistematis. 


\section{Student Segmentation}

The segmentation of students with Islamic economics and business faculties is divided into three parts, namely:

In this first segment, students see themselves as people who like to learn about art, culture, and history, like to make things instead of buying them, try new things, like challenges to do something they've never done before, like to do new and different things. , likes to learn everything even though it may not be of any use to him, and wants to know more about how the universe works.

From the information above, the students in the first segment can be called dynamic students. The tendency of these dynamic students to have a habit of doing things is not in accordance with the order or numbering, because their character tends to be visionary, able to giveanswers simple and meaningful. The types or segments of dynamic students usually have different, unstructured tendencies to do their tasks, even that tendency has an impact on their lifestyle, namely working smartly with maximum results based.

In the second part, students have a tendency to seek identity, they are more likely to experience times that change frequently, but in this section students do not consider maturity. In essence, these students do not have the characteristics of the science they are studying, but have a working method, and are simple and have short-term principles.

Results are the second goal of this student segment, because the tendency is how to create groups that can be invited to discuss to find the best solution, then at the scientific level, this student segment often forms small groups to introduce themselves.

In part Finally, students tend to follow the development of the model used by most people, preferring to lead groups, dress more in line with fashion and think that they are people educated, so they can refer to them as trendsetters. Thetrendsetters or conservative students most famousare those who are used to following development trends, especially clothes their, including clothes and styles. This is because they come from economically well-off and wellestablished families.

The approach taken is to approach it in style, appearance and what it has, so that its implementation is to measure the extent to which the level of ability to keep up with fashion and the times

According to the year study 2006 by Yohanes Sondang Kunto and Peter Remy Pasla, student lifestyle project research marketing University Christian broken petra, , results survey, from divided into three standards student, That is energetic student who like watching football activities, paying attention travel and sports..

\section{Conclusion}

From the information above, it can be concluded that Kiai Haji Achmad Siddiq Jember School of Islamic Economics and Business at the National Islamic University has three criteria, namely active students, students seeking identity, and conservative students. The researcher suggests that this research can be used as a reference for further research, increasing the number of differentiating variables and the number of different research subject populations as necessary), including individuals, institutions, or parts that contribute to this research.

\section{REFERENCES}

Armstrong, G \& Kotler P. 1997, Principles of marketing, first edition Jakarta: Erlangga.

Assael, Henry. 1984. Consumer Behavior and Marketing Action. Second Edition. California: Kent Publishing Co. 
Journal of Islamic Economics Perspectives, Volume 3. Issue 2 (2021)

Indriyo Gitosudarmo, 2008, Marketing Management, first edition, fourth printing, Publisher: BPFE - Yogyakarta.

IMARC (Indonesian Marketing Academy), 2015.

Joseph Plumer, 1974, "The Concept and Application of Lifestyle Segmentation". Journal of Marketing. Vol. January 38:33-37.

Kotler and Armstrong, (2004), Principles of Marketing, Seventh Edition, Salemba Empat Publishers, Jakarta.

Kasali, Reinald. (1998). Targeting the Indonesian Market: Segmentation, Targeting and Positioning. Main Library Gramedia. Jakarta.

Mowen, John, C., and Minor, M., (2002), Consumer Behavior Volume 1, Fifth Edition (translation), Erlangga, Jakarta.

Pride, William. M and OC Ferrel, 1995. Marketing Theory and Daily Practice, Binarupa Aksara, Jakarta.

Riesman, DR., N. Glazer, and R. Denney. 1950. The Lonely Crowd: A study of the Changing American Character. Yale University Press, New Haven, CT.

Sugiyono, 2014, Management Research Methodology, Alfabeta, Bandung

Yohanes Sondang Kunto and Peter Remy Pasla, JOURNAL OF MARKETING MANAGEMENT, VOL. 1, NO. 1, APRIL 2006:13-21 